\title{
RANCANG BANGUN SISTEM INFORMASI PENGARSIPAN SURAT MASUK DAN KELUAR STUDI KASUS PADA CV SUMBER KARYA TEKNIK
}

\author{
Desi Nurnaningsih ${ }^{1}$, Rachmat Destriana ${ }^{2}$, Djamaludin Syahlan Mubaroq ${ }^{3}$ \\ Universitas Muhammadiyah Tangerang / Fakultas Teknik, \\ Program Studi Informatika \\ Jl. Perintis Kemerdekaan 1/33 Cikokol Kota Tangerang TLP. 55793251, 55772949, \\ 55793802, 55736926 \\ Email: desi.nurnaningsih@umt.ac.id ${ }^{1}$ rachmat.destriana@gmail.com² \\ Jamaludinshaylan@gmail.com³
}

\begin{abstract}
Abstrak, Kegiatan persuratan pada suatu organisasi atau instansi adalah hal yang penting karena dapat menunjang perkembangan organisasi atau instansi dari sisi administrasi. Informasi-informasi penting maupun rahasia terkait dengan suatu instansi terkandung di dalamnya.Dengan menyimpan data atau keterangan tersebut, maka didapat surat yang disebut dengan arsip. Pada CV. Sumber Karya Teknik mengalami kesulitan dalam pengelolaan pengarsipan surat masuk dan surat keluar. Sistem pengarsipan yang berjalan saat ini dapat dikatakan masih kurang efisien dan efektif karena data surat masuk dan surat keluar sering tidak sesuai dengan data surat masuk dan surat keluar, dan semua proses masih dilakukan secara manual. Penulis merancangan sistem informasi pengarsipan surat masuk dan keluar berbasis web dengan bahasa pemrograman php dan MySQL sebagai database. System ini dikelola oleh satu pengguna sebagai super admin yang bisa mengelola surat masuk dan surat keluar untuk diarsipkan. Diharapkan dengan adanya sistem berbasis web ini dapat membantu perusahaan dalam pengarsipan surat menjadi lebih aman karna disimpan di dalam komputer.
\end{abstract}

Kata Kunci: Sistem Informasi, Pengarsipan Surat, Data, Php myAdmin, website.

\begin{abstract}
Correspondence in an organization or agency is important because it can support the development of the organization or agency from the administrative side. Important and confidential information related to an agency contained in it. By storing the data or information, a letter called an archive is obtained. In the CV. Sumber Karya Teknik experienced difficulties in managing the filing of incoming and outgoing letters. The current filing system can be said to be still less efficient and effective because the data of incoming and outgoing letters often does not match the data of incoming and outgoing letters, and all processes are still carried out securely. Of the problems that have been explained above, then the writer is planning to make a design of a system of information on archival information including web-based output with the php and MySQL programming as a database. This system is managed by a user as a super admin who can manage mailings and exits for filing. It is expected that with this web-based basis, it can help companies in the archiving documents save more than when stored in a computer.
\end{abstract}

Keywords: Information Systems, Letters Archiving, Data, Php myAdmin, website..

\section{PENDAHULUAN}

Surat adalah sarana komunikasi untuk menyampaikan infromasi tertulis oleh suatu pihak kepada pihak lain. Fungsinya sebagai sarana pemberitahuan, alat bukti tertulis, alat pengingat, bukti historis, dan pedoman kerja. Kegiatan persuratan pada suatu organisasi atau instansi adalah hal yang penting karena dapat menunjang perkembangan organisasi atau instansi dari sisi administrasi. Informasi-informasi penting maupun rahasia terkait dengan suatu instansi terkandung di dalamnya.

Salah satu pertimbangan perusahaan dalam penggunaan komputer diantaranya adalah dapat tersedianya data yang dapat 
memberikan informasi yang handal, cepat, akurat, dan tepat waktu. cara-cara manual mungkin masih saja dapat dipergunakan bila data yang diolah masih sedikit, tetapi bagaimana kalau data yang diolah jumlahnya sudah ratusan, atau bahkan ribuan, tentu saja sumber daya manusia yang mengolahnya akan merasakan kejenuhan dan bisa mengakibatkan informasi yang dihasilkan mungkin menjadi tidak akurat lagi.

Selain itu, keterlambatan informasi yang diperlukan dapat menyebabkan tertundanya pencapaian tujuan perusahaan dan akhirnya akan mengganggu perkembangan perusahaan. Makin lama makin dirasakan bahwa pengolahan data dengan cara manual semakin banyak menunjukkan kelemahan, Karena itu maka diperlukan suatu pengolahan data yang lebih canggih dengan menggunakan komputer. hal ini diperlukan untuk mendapatkan perolehan informasi yang handal, cepat, akurat, dan tepat waktu.

Pada perusahaan CV. Sumber Karya Teknik mengalami kesulitan dalam pengelolaan pengarsipan surat masuk dan surat keluar pekerjaan administrasi merupakan pekerjaan yang banyak menyangkut tentang data atau keterangan yang harus dicatat atau diolah secara teratur, sehingga segala sesuatu yang menyangkut tentang data atau keterangan tersebut mempunyai kegunaan atau nilai tertentu, sehingga arsip yang diperlukan dapat mudah ditemukan dan sistematis. dengan menyimpan data atau keterangan tersebut, maka didapat surat yang disebut dengan arsip. sistem pengarsipan yang berjalan saat ini dapat dikatakan masih kurang efisien dan efektif karena data surat masuk dan surat keluar sering tidak sesuai dengan data surat masuk dan surat keluar, dan semua proses masih dilakukan secara manual.

Berdasarkan uraian latar belakang tersebut, perlu diadakan pembangunan sistem informasi pengarsipan surat masuk dan surat keluar sehingga permasalahan tersebut diatas dapat diselesaikan untuk itu diajukan penelitian dengan judul "Rancang Bangun Sistem Informasi Pengarsipan Surat Masuk dan Keluar Berbasis Web Studi Kasus Pada CV. Sumber Karya Teknik"

\subsection{Identifikasi Masalah}

Berdasarkan latar belakang diatas, penulis mengindentifikasikan masalah sebagai berikut :

1. Kesulitan dalam pencarian data surat keluar dan masuk di bagian administrasi perusahaan karena pengolahan data arsip surat masuk dan surat keluar yang masih dicatat dalam buku besar dan belum menggunakan program aplikasi yang mendukung.

2. Tempat penyimpanan surat masuk dan surat keluar hanya dimasukan kedalam ms. excel.

3. Pengelolaan surat masuk dan keluar pada CV. Sumber Karya Teknik belum maksimal.

\subsection{Batasan Masalah}

Mengingat begitu luas permasalahan pengelolaan surat dan keterbatasan biaya, waktu, serta tenaga maka diperlukan pembatasan masalah. Bertolak dari permasalahan yang telah diidentifikasi di atas, penelitian ini hanya membatasi tentang Pengarsipan Surat Masuk dan Surat Keluar yang masih belum optimal. Dalam pelaksanaan penelitian diperusahaan CV. Sumber Karya Teknik ini. Peneliti membatasi permasalahan dalam hal :

1. Sistem yang dibangun hanya menyediakan informasi yang berkaitan dengan pengarsip surat masuk dan surat keluar pada CV. Sumber karya Teknik.

2. Sistem Informasi Pengarsipan Surat Masuk dan Surat Keluar ini hanya digunakan di bagian Administrasi dengan bagianbagian yang terkait lainnya yang ada di CV. Sumber Karya Teknik .

3. Sistem ini dibangun menggunakan bahasa pemrograman php berbasis web. Maksud di bangunnya sistem berbasis web adalah untuk kecepatan proses kerja, dan kemudahan pengaksesan yang bisa dilakukan dimana saja tanpa terbatas ruang dan waktu.

\subsection{Rumusan Masalah}


Berdasarkan latar belakang yang telah dijelaskan di atas, maka penulis merumuskan beberapa masalah sebagai berikut :

1. Bagaimana merancang sistem informasi pengarsipan surat masuk dan keluar pada CV. Sumber Karya Teknik?

2. Bagaimana mengimplementasikan sistem infromasi pengarsipan surat masuk dan keluar pada CV. Sumber Karya Teknik?

3. Bagaimana mempermudah proses pencarian surat masuk dan surat keluar?

\section{LANDASAN TEORI}

\subsection{Tinjauan Pustaka}

\subsubsection{Penilaian Kinerja}

Definisi Penilaian Kinerja menurut Adhawiyah (2017:120) adalah evaluasi kerja atau yang dikenal juga dengan penilaiain kinerja pada dasarnya merupakan proses yang yang digunakan perusahaan untuk mengevaluasi job performance. Jika dikerjakan dengan benar, hal ini akan memberikan manfaat yang penting bagi karyawan, supervisor departemen, SDM, maupun perusahaan. Sedangkan definisi Penilaian kinerja menurut Mathis dalam Hangga (2015) adalah proses mengevaluasi seberapa baik karyawan melakukan pekerjaan mereka jika dibandingkan dengan seperangkat standar, dan kemudian mengkomunikasikan informasi tersebut kepada karyawan.

\subsubsection{Pegawai}

Definisi pegawai menurut subekti dalam wibowopajak (2018) adalah orang pribadi yang bekerja pada pemberi kerja, berdasarkan perjanjian atau kesepakatan kerja baik secara tertulis maupun tidak tertulis, untuk melaksanakan suatu pekerjaan dalam jabatan atau kegiatan tertentu dengan memperoleh imbalan yang dibayarkan berdasarkan periode tertentu, penyelesaian pekerjaan, atau ketentuan lain yang ditetapkan pemberi kerja, termasuk orang pribadi yang melakukan pekerjaan dalam jabatan negeri.

\subsubsection{Analytical Hierarchy Process (AHP)}

Definisi AHP Menurut Saaty dalam Suryadi (2017:18) adalah suatu model pendukung keputusan yang akan menguraikan masalah multi faktor atau multi kriteria yang kompleks menjadi suatu hirarki. hirarki didefinisikan sebagai suatu representasi dari sebuah permasalahan yang kompleks dalam suatu struktur multi-level dimana level pertama adalah tujuan, yang diikuti level faktor, kriteria, sub kriteria, dan seterusnya ke bawah hingga level terakhir dari alternatif. Dengan hirarki, suatu masalah yang kompleks dapat diuraikan ke dalam kelompokkelompoknya yang kemudian diatur menjadi suatu bentuk hirarki sehingga permasalahan akan tampak lebih terstruktur dan sistematis.

\subsection{Tinjauan Studi}

Banyak penelitian yang sebelumnya dilakukan mengenai penilaian kinerja baru dan penelitian lain yang berkaitan. Dalam upaya mengembangkan dan menyempurnakan penelitian penilaian kinerja ini perlu dilakukan studi pustaka (literature review) sebagai salah satu dari penerapan metode penelitian yang akan dilakukan. Berikut adalah beberapa penelitian serupa yang sudah dilakukan sebelumnya yaitu :

1. Penelitian yang telah dijalankan oleh Saefudin dan Sri Wahyuningsih berjudul "Sistem Pendukung Keputusan Untuk Penilaian Kinerja Pegawai Menggunakan Metode Analytical Hierarchy Process (AHP) Pada RSUD Serang". Sistem ini dirancang untuk dijadikan solusi awal dalam memecahkan masalah yang terjadi dimana penilaian yang dilakukan masih menggunakan cara manual sehingga proses penilaian kinerja pegawai menjadi lambat dan belum akurat. Dengan menggunakan sistem penunjang keputusan pada kasus ini maka admin dapat mengelola data penilaian kinerja pegawai serta menghasilkan ranking dari hasil perhitungan bobot nilai pegawai dapat dilakukan dengan mudah dan akurat.

2. Penelitian yang telah dijalankan oleh Ahmad Faisal berjudul "Aplikasi Sistem Pendukung Keputusan Penilaian Kinerja Karyawan untuk Kenaikan Gaji pada PT AAA". Penelitian ini menggunkan PHP sebgai bahasa pemograman dan MySQL sebagai database pada 
proses perancangan. Tujuan dari penelitian ini adalah menghasilkan aplikasi perangkat lunak untuk memudahkan proses penilaian kinerja pegawai untuk kenaikan gaji.

3. Penelitian yang telah dijalankan oleh Frieyadie berjudul "METODE AHP SEBAGAI PENUNJANG KEPUTUSAN UNTUK PENILAIAN KINERJA KERJA KARYAWAN SPBU". Sistem yang diusulkan pada penelitian ini hanya membahas metodenya saja tanpa implementasi program aplikasi. Permasalahan yang redapat pada penelitian ini adalah Proses penilaian tersebut masih dilakukan secara manual, dengan manual relatif terjadi ketidak akuratan data, dan juga diimplementasikan menggunakan aplikasi Microsof Excel, sehingga memerlukan waktu yang cukup lama untuk pengolahan data. Selain itu penilaian bersifat subyektif dan belum relevan dengan keadaan yang sebenarnya, sehingga tidak dapat digunakan sebagai sumber dasar pengambilan keputusan. Dengan adanya Sistem pendukung Keputusan dapat memberikan alternatif keputusan yang dapat pemecahan masalah yang ada, sehingga keputusan yang dibuat menjadi lebih baik.

\subsection{Hipotesis}

Hipotesis dalam penelitian ini adalah: diduga bahwa belum adanya penelitian terhadap penilaian kinerja pegawai yang menggunakan metode Analytical Hierarchy Process (AHP) dan dibangun menggunakan Vissual Studio 2010 atau VB.Net 2010. Dengan merujuk dari beberapa penelitian yang sebelumnya telah dilakukan, maka dari itu penulis memberanikan diri untuk menyusun dan melakukan penelitian mengenai penilaian kinerja pegawai dengan menggunakan metode Analytical Hierarchy Process (AHP) dan VB.Net 2010.

\section{METODOLOGI PENELITIAN}

\subsection{Metode Penelitian}

Jenis penelitian adalah penelitian kualitatif, yaitu serangkaian kegiatan atau proses untuk mengungkapkan prosesproses informasi sebagai dasar dalam perancangan sistem informasi dengan melakukan wawancara langsung menggunakan daftar pertanyaan kepada pihak-pihak terkait.

Hasil penelitian berupa aplikasi Sistem Informasi pengarsipan surat masuk dan keluar pada CV Sumber Karya Teknik yang berguna untuk mengoptimalkan pengarsipan surat, data surat masuk, dan data surat keluar untuk mempermudah perusahaan dalam melakukan manipulasi (penambahan, menghapus, mengedit, serta pencarian) terhadap data yang ada menjadi lebih efisien dan efektif.

\subsection{Metode Pengumpulan Data}

1. Metode Observasi (Observasi) Observasi atau pengamatan merupakan salah satu teknik pengumpulan data atau fakta yang cukup efektif untuk mempelajari suatu sistem. Dengan cara melihat langsung ketempat yang sedang menjadi penelitian pada CV. Sumber Karya Teknik yang beralamat Jl. Jati Uwung, Tangerang, Banten.

2. Metode Wawancara (Interview)

Peneliti telah menyiapkan daftar pertanyaan yang berkaitan dengan pengumpulan informasi, untuk ditanyakan kepada: Ibu Lia dan kepala staff CV. Sumber Karya Teknik.

3. Metode Studi Pustaka (Library)

Metode untuk mendapatkan informasi dan data dari beberapa sumber atau dengan membaca dan mempelajari buku-buku yang relevan dengan judul penulis. Data-data tersebut digunakan untuk membantu penganalisaan dan perancangan laporan yang terkait.

a. Metode Analisis Sistem

Pada metode ini penulis menganalisa sistem yang berjalan, kekurangan dari sistem dan solusi yang diusulkan untuk pembangunan dan perkembangan sistem selanjutnya. Penelitian ini menggunakan Unified Modelling Language (UML) untuk menggambarkan skema sistem yang sedang berjalan

\section{b. Metode Perancangan Sistem}

Tahap desain yaitu tahap dalam menentukan proses data yang diperlukan oleh sistem baru dengan tujuan memenuhi kebutuhan user. Teknik 
perancangan yang digunakan dalam penelitian adalah metode perancangan berorientasi objek (UML). Pada proses perancangan sistem yang dilakukan adalah:

1. Perancangan spesifikasi sistem dimodelkan dengan Use Case Diagram.

2. Perancangan antar muka pengguna meliputi perancangan tampilan utama, form Input, form surat masuk form surat keluar form pengarsipan surat dan form output.

3. Perancangan database atau struktur data dan hubungan antar data dimodelkan dengan class diagram.

4. Perancangan infrastructure architecture (hardware dan software).

\section{c. Tahapan Penelitian}

Tahapan penelitian yaitu tahapan yang akan dilakukan untuk mempermudah dalam melakukan penelitian. Metode pengembangan sistem yang digunakan adalah metode Waterfall.

Secara garis besar metode Waterfall mempunyai langkah-langkah yaitu analisa kebutuhan, desain sistem, penulisan kode program, Pengujian Program, penerapan program, dan pemeliharaan. Proses testing dilakukan dengan melakukan percobaan dan pembuktian terhadap fitur-fitur sistem yang telah dibangun apakah telah sesuai dengan kebutuhan atau masih terdapat kekurangan.

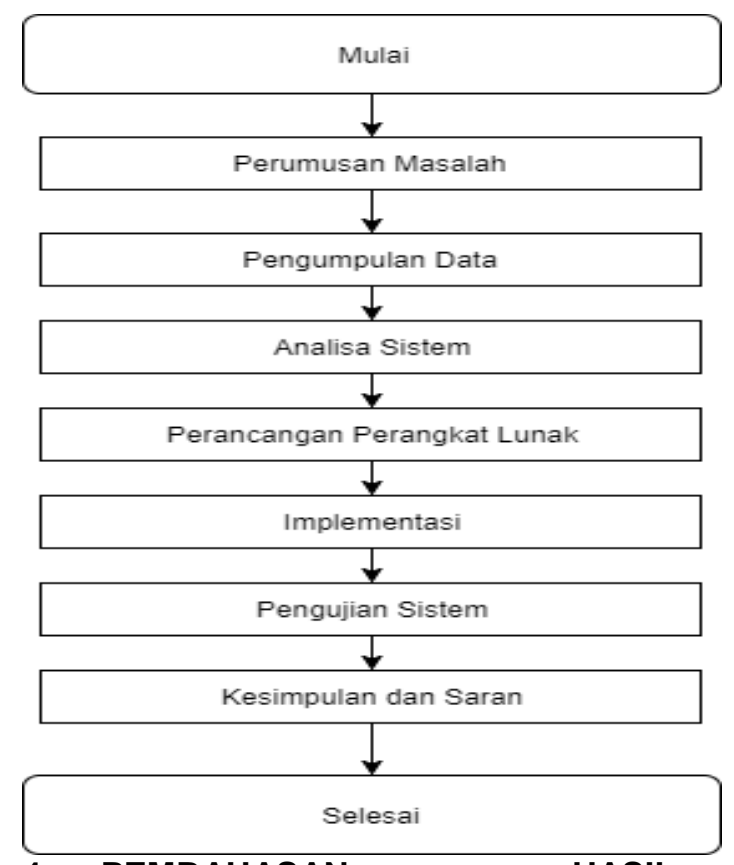

4. PEMBAHASAN

HASIL PENELITIAN

\subsection{Flow Chart Sistem Berjalan}

Flow Chart dari sistem yang berjalan saat ini seperti terlihat dalam gambar IV.1 berikut ini.

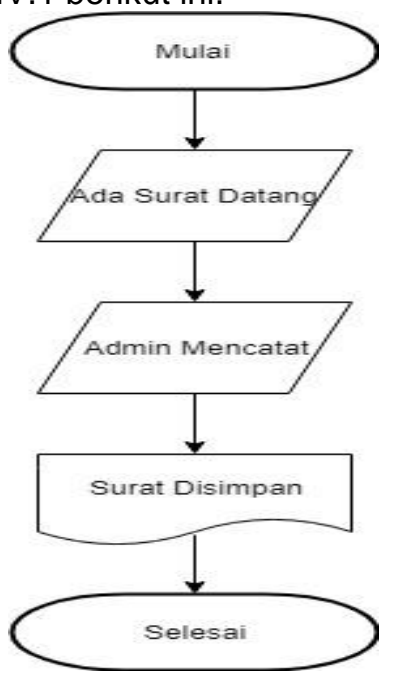




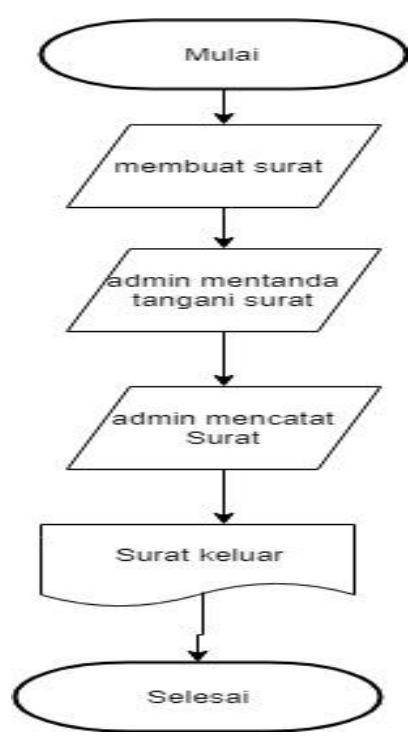

Gambar IV-1 Flow Chart sistem berjalan

\subsection{Diagram Use Case}

Diagram use case menggambarkan alur kerja sistem dengan cara yang sangat sederhana, fungsi utama dari sistem dan berbagai jenis pengguna yang akan berinteraksi dengan sistem, sebagaimana gambar IV.2. berikut ini:

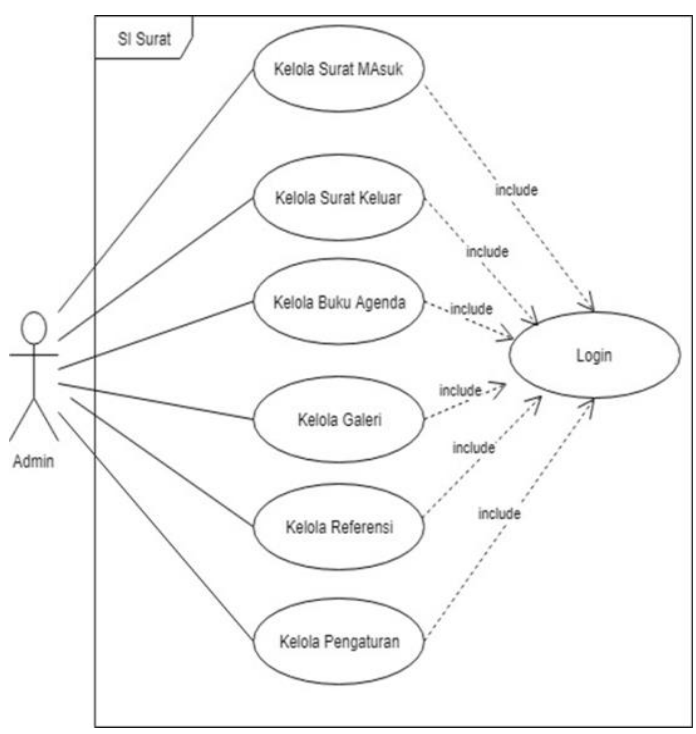

Gambar IV-2 Diagram use case sistem usulan

\subsection{Rancangan UI}

\subsubsection{Tampilan Menu Utama}

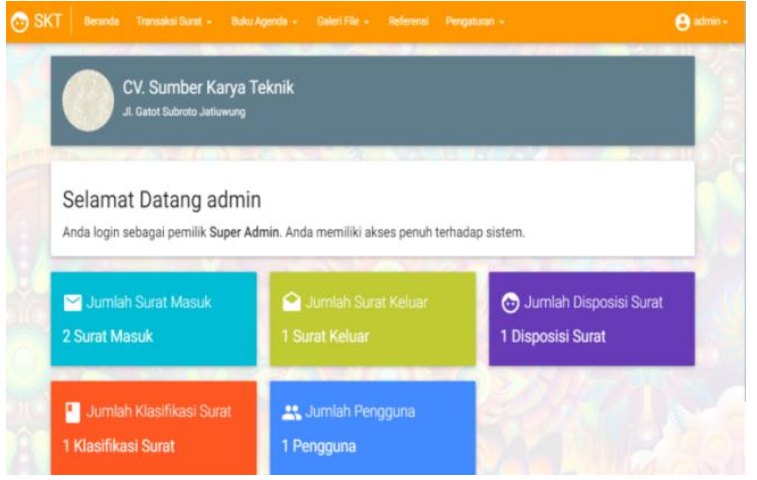

Gambar IV-3. Menu Utama

\subsubsection{Tampilan Transaksi Surat Masuk}

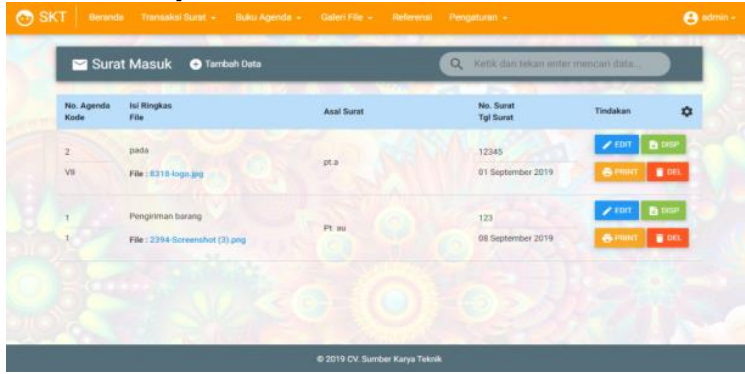

Gambar IV-4. Tampilan Transaksi Surat Masuk

\subsubsection{Tampilan Laporan}

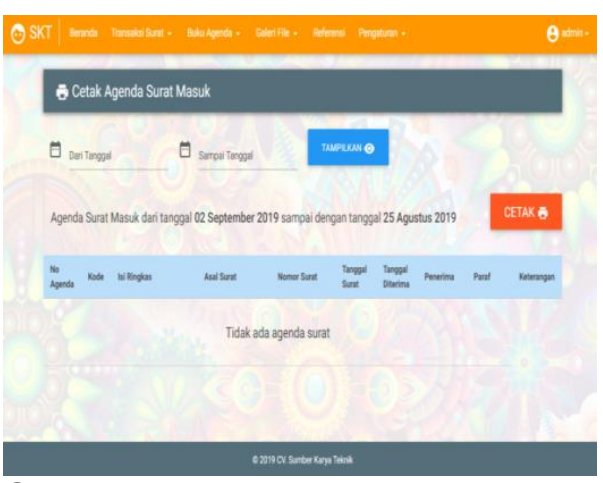

Gambar IV-5. Laporan

\section{KESIMPULAN}

Berdasarkan hasil penelitian yang telah dilakukan dapat diambil kesimpulan sebagai berikut:

1. Dengan cara melakukan pembuataan analisis dan perancangan sistem pengarsipan surat masuk dan keluar sehingga menjadi sebuah aplikasi yang dapat mempermudah perusahaan dalam pengarsipan surat masuk dan keluar pada CV. Sumber Karya Teknik. 
2. Pada tahap implementasi yang dilakukaan pada CV. Sumber Karya Teknik diharapkan sampai tahap testing, sehingga Sistem informasi secara fungsional diharapkan dapat membantu proses kinerja pada CV. Sumber Karya Teknik.

3. Hasil pengujian menunjukan bahwa fungsi - fungsi yang terdapat pada aplikasi berjalan dengan baik dan sesuai dengan kebutuhan dan rancangan, sehingga dapat mempermudah proses pencarian.

\section{DAFTAR PUSTAKA}

[1] Abas Kartadinata (2012). "Perbandingan Hasil Belajar Model Cooperative Learning Dengan Model Science Technology Society Pada Siswa Kelas X Man 1 Model Kota Bengkulu". Jurnal Exacta. Vol. X No. 1 Juni 2012.

[2] Abdulloh, Rohi. 2016. Easy \& Simple Web Programming. Jakarta: PT Elex Media Komputindo.

[3] Atyanto Mahatmyo. 2014. Sistem Informasi Akuntansi Suatu Pengantar. Yogyakarta: Deepublish.

[4] A.S Rosa dan M. Shalahuddin. 2014. Rekayasa Perangkat Lunak Terstruktur dan Berionterasi Obje. Informatika. Bandung.

[5] Budiman, Agustiar.2012 Pengujian Perangkat Lunak dengan Metode Black Box Pada Proses Pra Registrasi User Via Website. Makalah, halaman: 4

[6] Faridl, Miftah. 2015. Fitur Dahsyat Sublime Text 3. Surabaya: LUG STIKOM.

[7] Hartono, Jogiyanto. 2010. Metodologi Penelitian Bisnis Edisi 6. Yogyakarta: BPFE.

[8] Jaluanto, S. Punjul and . T. Sistem Informasi Manajemen, Yogyakarta: Deepublish, 2016.

[9] Lamuddin finoza. (2009). Aneka Surat Sekretaris dan Surat Bisnis Indonesia Revisi 3. Jakarta: Diksi Insan Mulia.

[10]Mahdiana, Deni.2011. Analisa Dan Rancangan Sistemlnformasi Pengadaan Barang DenganMetodelogi Berorientasi
Obyek (Studi Kasus : PT. Liga Indonesia). Jurnal TELEMATIKA MKOM. Jakarta: Universitas Budi Luhur. Vol. 3 No .2, September 2011.

[11]Maulani \& Jubilee Enterprise. 2005. Kiat Merawat Gigi Anak. Jakarta : Gramedia

[12] Nugroho. Adi. 2010. Analisis Dan Perancangan Sistem Informasi dengan Metodologi Berorientasi Object. Bandung: Informatika.

[13] Pressman, Ph.D.Roger S. 2010. Pendekatan Praktisi Rekayasa Perangkat Lunak. Edisi 7. Penerbit Andi. Yogyakarta. Halaman 45 -46.

[14]Rusdiana \& Moch.Irfan. 2014. Sistem Informasi Manajemen. Pustaka Setia,Bandung

[15] Sidik, Betha. 2014. Pemrograman Web dan PHP. Bandung: INFORMATIKA.

[16] Sutanto, Ery Hermawan. 2014. PAS Sistem Informasi Penjualan Online Untuk Tugas Akhir. Semarang: Wahana Komputer. Yogyakarta: Andi Offset.

[17] Sutabri,Tata.2012. Konsep Sistem Informasi.Yogyakarta:ANDI.

[18] Swastika, Windra. 2006. "PHP 5 dan MySQL 4 (Proyek Shopping Cart 1). Jakarta: Dian Rakyat.

[19] Taufiq, Rahmat. 2013. Sistem Informasi Manajemen. Yogyakarta: Graha IImu.

[20]Whitten, Jeffery L., Bentley, Lonnie D, and Dittman, Kevin C. (2004). Metode Desain dan Analisis Sistem. Yogyakarta: Penerbit Andi dan Mc Graw Hill Education.

[21] Winarno, Edy; Ali Zaki, SmithDev. 2014. "Pemrograman Web Berbasis HTML5, PHP, dan JavaScript". Jakarta: PT Elex Media Komputindo. 